\title{
Views of Advisors About Students' Knowledge on Scientific Research Ethics an Example from Sakarya University ${ }^{*}$
}

\author{
Nazire Burçin HAMUTOĞLU ${ }^{* *} \quad$ Özcan Erkan AKGÜN ${ }^{* * *}$ \\ Ezgi Pelin YILDIZ ${ }^{* * *}$
}

\begin{abstract}
In this study the views of graduate thesis advisors at Sakarya University, Institute of Educational Sciences (5 Male, 4 Female) are analysed regarding their students' knowledge on scientific research ethics (SRE). This was done via phenomenology, one of the qualitative research methods. The data were collected with structured interview questions and also additional probe questions when needed. The questions were written by the researchers after performing a comprehensive literature study. Expert opinions were asked for after the interview form was prepared. The experts evaluated the suitability of the questions in terms of scope and language and found them to be sufficient. Moreover, three advisors were chosen randomly among the target group to be asked the questions in order to check clarity and expediency before data collection. The findings of the research showed that knowledge about the SRE of most of the students was insufficient, and the educational need for this matter was provided by the advisors. It was also reported by the advisors that most of the students' knowledge about the SRE was learnt by direct experiences while preparing their thesis and their levels of awareness about the importance of the subject were very low before the thesis stage. The advisors also mentioned that the curricula do not directly include a course on the scientific research ethics; a limited content is taught within the research methods course. It was stated that real life cases, examples and experiences might be effective in enhancing students' awareness levels regarding the SRE. Developing empathy was mentioned as an important technique for creating awareness. Consequently it is thought that taking the findings of this study into account may improve students' levels of awareness on codes of ethics. Research teams could be created within universities and they could focus on providing research and writing support to the students who are at thesis stage. Regarding systematic approach, the awareness regarding plagiarism should be increased from the undergraduate level to post graduate studies.
\end{abstract}

Keywords: Ethics, Scientific Research Ethics, Plagiarism, Views of the Academic Staff.

\footnotetext{
* This study is improved and extended version of the paper that was made oral presentation at ERPA Congress 2015 at Athens, Greece.

** Sakarya University, bhamutoglu@sakarya.edu.tr

*** Istanbul Medeniyet University, ozcan.akgun@medeniyet.edu.tr

**** Yakın Doğu Üniversitesi, ezgipelin.yildiz@neu.edu.tr
} 


\title{
Bilimsel Araştırma Etiği İle İlgili Öğretim Üyelerinin Öğrencileri Hakkındaki Görüşleri Sakarya Üniversitesi Örneği
}

\begin{abstract}
Öz
Bu çalışmada Sakarya Üniversitesi Eğitim Bilimleri Enstitüsü (5' erkek, $4^{\prime}$ ü bayan) öğretim üyelerinin öğrencilerinin bilimsel araştırma etiği yeterlilikleri açısından görüşleri nitel bir araştırma yöntemi olan olgu bilim deseni ile incelenmiştir. Çalışmada öğretim üyelerinin görüşleri yapılandırılmış görüşme formu ile alınmıştır. Görüşme formundaki sorular, kapsamlı bir literatür çalışması yapılarak araştırmacılar tarafından oluşturulmuştur. Görüşme formunun hazırlanmasından sonra uzman görüşüne başvurulmuştur. Uzmanlar soruların kapsam ve dil açısından uygunluğunu değerlendirerek yeterli bulmuşlardır. Ayrıca sorular hedef kitleden rastgele seçilerek alınan 3 öğretim üyesi ile görüşülerek anlaşlırlık ve amaca uygunluk açısından kontrol edilmiştir. Araştırma bulguları, öğrencilerin büyük çoğunluğunun Bilimsel Araştırma Etiği ile ilgili bilgilerinin yetersiz olduğunu, bu konudaki eğitim ihtiyaçlarının daha çok danışman hocaları tarafından sağlandığını göstermektedir. Ayrıca öğrencilerin Bilimsel Araştırma Etiği ile ilgili bilgilerini tez yazarken, süreçte yaşadıkları deneyimlerle öğrendikleri, tez öncesinde konunun önemine ilişkin farkındalık düzeylerinin çok düşük olduğu öğretim üyeleri tarafından ifade edilmiştir. Bilimsel araştırma etiği ile ilgili direkt okutulan bir ders olmadığı, sadece bilimsel araştırma yöntemleri dersinde sınırlı bir içerik işlendiği öğretim üyeleri tarafından belirtilmiştir. Bilimsel araştırma etiği konusunda öğrencilerin farkındalık düzeylerini arttırmada örnek olayların, örneklerin ve yaşanmış olayların etkili olacağı ifade edilmiştir. Empati kurma, BAE konusunun önemini fark ettirmede önemli bir teknik olarak belirtilmiştir. Buna göre gelecekte BAE ile ilgili yapılacak çalışmalarda, bu çalışmanın bulguların dikkate alınmasının Bilimsel araştırma etiği konusunun önemi ve ciddiyeti ile ilgili öğrencilerin farkındalık düzeylerini artıracağı düşünülmektedir.
\end{abstract}

Anahtar Kelimeler: Etik, Bilimsel Araştırma Etiği, İntihal, Öğretim Üyeleri Görüşleri.

\section{INTRODUCTION}

The concept of values plays an important role in today's societies in which the change and development are witnessed in every area. A sub-dimension of this is academic ethics values, which studies and research conducted to improve the educational and scientific level of a society should possess. Academic ethics consist of the behavioural patterns which should be exhibited in scientific research activities (Özder, Işıktaş, Erdoğan, 2014). These behavioural patterns can be illustrated by certain challenges such as showing the sources used in conducting the scientific research, identifying the data in accordance with certain rules; in short, adhering to the academic writing principles. Re- cent diversity of technological facilities have brought about the problems about the ethical values in scientific studies and research (Öncü, 2010; Uçak and Birinci, 2008). An increase in the number of problems about the academic ethical value have drawn attention to this point and made it imperative to act responsibly on this subject (Sevim, 2014). The academicians who perform research and studies that pave the way for the changing and development of the society should address this subject even more because they are the role models of the society.

It is possible to see the importance of ethics in areas such as business, health, genetics, media, IT, communication, and education. Although 
ethics is conceptually different in every field, all researchers need to continue focusing on it. According to Schienke et al. $(2009,2010)$ and Tuana (2010), ethics education for researcher includes three aspects: "procedural," "intrinsic," and "extrinsic". These aspects include responsibility, values and broader impacts (Briggle, et. al, 2016). Reyes, Kim and Weaver (2016) claim that normative and behavioural approaches should be integrated into business ethics' courses. In addition, the authors introduce a variety of pedagogical strategies; however, they may have overestimated the importance of synthesizing the approaches. Joly et al. (2016) argue the importance of developing a consistent method while selecting the review process for genomics and bioinformatics projects. Another important issue of the paper claims that several ethics review policies are not enough to determine the appropriate level of a review. The results of the paper are synthesised for both researchers and policymakers. Ammar, Mandil and El-Feky (2016) agree with the values of honesty, objectivity, integrity, carefulness, and openness. Furthermore, they state the necessity to have respect for intellectual property and colleagues, as well as social responsibility. According to these values, publishing responsibly and protecting human subject should be taken into account in ethical principles of education research. Throughout a study which was completed in 2002, Turkish Academy of Sciences Committee of Science Ethics reviewed the importance of ethics in educational technologies. The committee highlighted the duties and responsibilities of scientists and emphasized the importance of meeting the professional standards: being objective, honest and open during the research process as well as mentioning the contribution made by the research-conducting scientists (Academy of Sciences Committee, 2002).
Especially with the rapid increase of new technologies, there needs to be more focus on ethical issues. The facilities where the internet is accessible make it easier to obtain information. Corley, Kim and Scheufele (2016) claim beneficial perception of technologies in social and ethical responsibility. More often using digital libraries and web 2.0 tools such as wiki, social networks and blogs might bring certain ethical problems. Gastel and Day (2016) state the impact of electronic eras on basic ethics norms. When looking at the literature, there are some studies examining the considerations from both academicians and students to promote the awareness of publications on research ethics (Engle and Smith, 1990; Pınar, 2002; Köklü, 2003; Hollander, 2009; Türkyılmaz and Kaygisız, 2012; Maya, 2013, Özder, Işıktaş and Erdoğan, 2014; Hamutoğlu, Yıldız and Akgün, 2015; Zhang, 2015; Corley, Kim and Scheufele, 2016; Pruzan, 2016). Therefore, scientific ethics should also be considered in education research.

As seen in the studies mentioned above, the importance of ethics is discussed. Organizations that monitor the ethical problems, and ethical codes within universities are needed, so that the academicians as researchers can be honest and avoid ethical violations in their scientific studies. Hence, it is necessary to provide the academicians with research training and help them develop the behaviour a researcher needs on the subject of ethics during their education (Köklü, 2003). Finally, the importance of scientific research ethics in graduate programs is clearly seen. This study aims to take different perspectives and investigate the advisors' views about their students' knowledge of scientific research ethics. In graduate programs there are some research method courses to provide learners with necessary awareness and skills about ethic codes. Whether or not they are effective and success- 
ful is a question. In this study we will try to focus on graduate students' ethical problems from the perspectives of their advisors. In all research, ethical considerations play a role and all investigators must be aware of and attend to

\section{Nomenclature}

$\begin{array}{ll}\text { SRE } & \text { Scientific Research Ethics } \\ \text { SRM } & \text { Scientific Research Methods } \\ \text { HEC } & \text { Source of Higher Education Council } \\ \text { LSF } & \text { Lecture on Specialized Field }\end{array}$

\section{METHOD}

This study was conducted with phenomenology design which is a qualitative research method. Phenomenology studies require a detailed examination of subjects we do not have thorough knowledge about but are aware of (Yıldırım and Şimşek, 2006). In order to collect data the views of advisors at Sakarya University Institute of Educational Sciences were voicerecorded through interview sessions.

\subsection{Study Group}

A purposive sample of 9 experienced graduate advisors (5 males, 4 females) from 3 different departments of Sakarya University, Institute of Educational Sciences formed part of the inves- the ethical considerations related to their studies (Engel, 2016). This paper will highlight the common ethical problems of graduate students.

Table 1. Participants' Demographic Characteristics

\begin{tabular}{llccc}
\hline Participants & Academic Title & $\begin{array}{c}\text { Professional Ex- } \\
\text { perience (year) }\end{array}$ & $\begin{array}{c}\text { The number of } \\
\text { students }\end{array}$ & Department \\
\hline F1 & $\begin{array}{l}\text { Associate Prof. } \\
\text { Dr. }\end{array}$ & 8 & 9 & Primary School \\
\hline F2 & Assistant Prof. Dr. & 4 & 6 & $\begin{array}{c}\text { Educational Sci- } \\
\text { ences }\end{array}$ \\
\hline F3 & $\begin{array}{l}\text { Associate Prof. } \\
\text { Dr. }\end{array}$ & 9 & 10 & Primary School \\
\hline F4 & Associate Prof. & 18 & 3 & Primary School \\
\hline M1 & Dr. & 12 & 3 & Primary School \\
\hline M2 & Assistant Prof. Dr. & 8 & 3 & Primary School \\
\hline M3 & Associate Prof. Dr & 5 & 2 & Primary School \\
\hline Associate Prof. & Dr. & 8 & 10 & Comp. and Inst. \\
\hline M5 & Associate Prof. Dr & Techn. \\
\hline
\end{tabular}


Techn.

\subsection{Data Collecting Tool and Collection of the Data}

The views of the advisors were collected with a structured interview form by voice recording through an interview protocol. The questions in the protocol were prepared by the researchers after a comprehensive literature review on scientific research ethics (SRE). While creating the questions, the opinions of the students on scientific research ethics were also taken into consideration. After the preparation of the questions, 4 experts from different departments of Institute of Educational Sciences who have more than 4 years of professional experience and had already taught Scientific Research Methods were asked for their opinions to determine the linguistic, cultural and conceptual suitability of the questions. A focus group interview was held with a 5-member group, similar to our study group the department of Education of Computer and Instructional Technologies (1) and Educational Sciences (4) to determine the clarity of the questions. The time of the interview was 10 to 15 minutes. After completing the necessary revision, the final interview protocol with questions was prepared. The data collection tool includes 5 open-ended and 4 descriptive questions. The open-ended questions are as follows: “. Do you find the knowledge that your thesis students have on Scientific Research Ethics (SRE) to be adequate?"; "Do you think your thesis students receive adequate education on SRE "; " How do your thesis students meet their educational needs for SRE?" ; "If we were to prepare a book on SRE, what would you want it to include?" and "What are the suggestions and opinions you want to add on this subject?". While the questions were being asked to the participants, they were also requested to explain the reasons or indicators of the statement. The participation in the interview was voluntary. Data collected through voice recordings were analysed by two researchers. The recorded data were sent to the participants, and their transcripts were confirmed before the analysis. The data, which we think will enlighten our study, were put in quotes without any changes in the findings section to support the validity of results (Yıldırım and Şimşek, 2006).

\subsection{Analysis of the Data}

Content analysis was utilised for analyzing the data. According to Tavşancıl and Aslan (2001), the content analysis is a scientific approach that provides an objective and systematic examination of verbal, written, and other materials. The findings obtained from the content analysis were accordingly examined. Frequency tables were generated concerning the opinions of the advisors. Moreover, quoted directly, the findings were presented in line with the opinions of the participants.

\section{RESULTS}

A code and themes list was generated after the opinions were analysed. These codes are given in the tables along the frequencies under the title of the questions. The analysed results were presented in the tables below.

The answers given by advisors to the question "Do you find the knowledge that your thesis students have on Scientific Research Ethics (SRE) to be adequate?" are summarised in Table 2 . 
Table 2. Do you find the knowledge that your thesis students have on Scientific Research Ethics (SRE) to be adequate?

\begin{tabular}{cccc}
\hline & Strongly inadequate & They learn in the thesis stage & They learn through experiences \\
\hline Participants & 7 & 1 & 1 \\
\hline
\end{tabular}

Table 2 includes the answers given by the advisors to the question "Do you find the knowledge that your thesis students have on Scientific Research Ethics (SRE) to be adequate?". Among the participants, 7 people gave the answer "strongly inadequate", 1 of them "they learn in the thesis stage", and 1 of them "they learn through experiences". The remarkable point in the answers given is that participants F4 (laughing) and F2 (sighing) indicated through body language that students are not adequate in SRE at all. And the statements of participant F1 "They take everything from just a one source especially in the beginning part of the thesis" and participant M5 "My previous thesis student failed just because of that; we wrote the thesis all over again" reveal the deficiency of students on the matter.

The answers given by the advisors to the question "Do you think your thesis students receive adequate education on SRE?" are summarised in Table 3.

Table 3. Do you think your thesis students receive adequate education on SRE?

\begin{tabular}{lcc}
\hline & No (SRM course is inadequate) & Yes (SRM course is inadequate) \\
\hline Participants & 7 & 2 \\
\hline
\end{tabular}

As seen in Table 3, 7 of the participants reported that students do not receive adequate education on SRE; 2 of them reported that they receive adequate education and the Scientific Research Methods course is adequate in the matter. For the individual views of the participants, the participant M5 who supported that students do not receive adequate education on SRE unfolded the deficiency of the students on SRE through the statements "There are two important problems: firstly, they won't read the thesis writing manual; secondly, no one asks about SRE. In total, 6 students from whole graduate programs participated in the seminar course about ethic codes in this semester. The low participation could be linked to the fact that people were not aware of the importance of the course." Similarly, participant F2 stated "They take the SRM course in the doctorate/master programs but I think it remains on the theoretical level. I believe these studies should be performed one-to-one. Once, I showed a thesis student how it works" and supported the deficiency of the students on this matter.

The answers given by the advisors to the question "How do your thesis students meet their educational needs for SRE?" are summarized in Table 4 . 
Table 4. How do your thesis students meet their educational needs for SRE?

\begin{tabular}{lll}
\hline Themes & Codes & Frequency (f) \\
\hline \multirow{4}{*}{ Procedural Ethics } & There is no direct course & 7 \\
\cline { 2 - 3 } & Source of Higher Education & 1 \\
& Council (HEC) & \\
\cline { 2 - 3 } & SRM textbook & 1 \\
\cline { 2 - 3 } & Lecture on specialized field (SF) & 1 \\
\hline \multirow{2}{*}{ Intrinsic Ethics } & Meeting with advisor & 7 \\
\cline { 2 - 3 } & Experiences & 7 \\
\hline \multirow{3}{*}{ Extrinsic Ethics } & Instruction from advisor & 2 \\
\cline { 2 - 3 } & Thesis stage & 7 \\
\cline { 2 - 3 } & Source Suggestion & 7 \\
\hline
\end{tabular}

As can be seen in Table 4., the interview stage was divided into three themes. The first one, procedural ethics, generated the following responses from all 7 participants: "There is no direct course". One respondent said that "The students seek SRE through the source of Higher Education Council (HEC) when they need a direction." Another respondent referred to SRM textbook and the last one attended lectures on specialized field. When it comes to the second theme, 7 participants agreed that meet- ing with advisors and experience gained through the academic progress allowed them to meet their educational needs. Finally, within the extrinsic ethics, 7 respondents stressed the importance of thesis stage and source suggestions- 2 participants sought instructions from their advisor when meeting SRE demands.

The answers given by the advisors to the question "If we were to prepare a book on SRE, what would you want it to include?" are summarised in Table 5.

Table 5. If we were to prepare a book on SRE, what would you want it to include?

\begin{tabular}{|c|c|c|}
\hline Themes & Codes & $\begin{array}{ll}\text { Frequency (f) } \\
\end{array}$ \\
\hline \multirow[t]{2}{*}{ Procedural Ethics } & $\begin{array}{ll}\begin{array}{l}\text { Scientific } \\
(\mathrm{SRM})\end{array} & \text { Research } \\
\end{array}$ & Methods 2 \\
\hline & Plagiarism & 1 \\
\hline \multirow{2}{*}{ Intrinsic Ethics } & Awareness & 5 \\
\hline & Empathy & 1 \\
\hline \multirow{6}{*}{ Extrinsic Ethics } & True Life Event & 2 \\
\hline & Information & 4 \\
\hline & Case & 1 \\
\hline & News & 1 \\
\hline & Practice & 1 \\
\hline & Example & 1 \\
\hline
\end{tabular}

The same themes were followed in Table 5 which summarised the answers to the question on the inclusion of ideas in a book on SRE. Under the procedural ethics, 2 participants 
recommended SRM within the book. One of the respondents stated that "SRE should be defined because there are many concepts about ethics. Of course, it is a body of rules belonging to an institution; however, everything about SRE should be addressed so that ethics can be understood. Moreover, the basic problems should be mentioned. There are many factors such as authorship, copyright, fabrication, publication of the same data by duplication and division, tempering with data, twisting the research in case it does not meet the expectations or reflecting it in the desired way. The sources are presented prejudicially. All of these should be explained with examples and in practice." (F2). For 1 participant a mention on plagiarism was important as they said that "Types of plagiarism, duplication of the publications should be included." (M2). Within the intrinsic ethics, 5 participants believed the awareness about SRE would comprise an important element of the book. One of the participant stated to imply the importance of awareness on SRE that "The importance of the matter should be told. What is it? Why is it important? What is SRE? Why are there rules? Examples should be given concerning the plagiarism. One should say 'This is plagiarism. The reasons are this, that.' There is a problem in the dimension of faith and awareness; ethics is a matter of 'I can take it or leave it.' Types of plagiarism should be explained and exemplified. The problems in students' minds should be solved. The awareness that each letter in the written work belongs to that person should be instilled." (M5) Among the participants emphasised the importance of awareness for the content, too. F1 provided the following statements and supported the importance of awareness in the book content: "Scientific research ethics should be explained with examples rather than definitions. Awareness should be created for what the plagiarism and information should be provided on what its sanctions are." There is another code which is related with the intrinsic ethics- empathy. 1 participant sought empathic stories about the SRE should be considered within the book. The last one, extrinsic ethics included information, true life events, case, news, practice and examples; should be content of the books. For 4 participants it was important that the book should contain general information and a policy about the ethics. Furthermore, for 2 participants, it is stated the impact of true life stories and in another all of 1 participants emphasized "case, news, practice, example" should be taking into account while preparing the books content.

The answers given by advisors to the question "What are the suggestions and opinions you want to add on this subject?" are summarized in Table 6.

Table 6. What are the suggestions and opinions you want to add on this subject?

\begin{tabular}{lll}
\hline Themes & Codes & Frequency (f) \\
\hline & Compulsory Course & 2 \\
& Systematic approach & 1 \\
& From Theory to Practice & 1 \\
Procedural Ethics & SRE Thesis & 1 \\
& APA-5 and APA-6 Bibliography & 1 \\
& Long-Term Practices & 1 \\
& A three-week course on ethics & 1 \\
\hline \multirow{5}{*}{ Intrinsic Ethics } & Beliefs and Values & 1 \\
& Empathy & 1 \\
& Awareness on the part of In- & 1 \\
& structor & 3 \\
\hline \multirow{2}{*}{ Extrinsic Ethics } & Awareness & 3 \\
& Cases & 1 \\
\hline
\end{tabular}


As shown in the table above, three different themes of procedural ethics included the following: 2 participants wanted a compulsory SRE course; one person suggested a systematic approach, one person felt the need to implement theory into practice. In terms of APA-5 and APA- 6 bibliography, one person suggested its inclusion in the subject. One participant wanted to include long-term practices, and another one stated the need for a three-week course on ethics. In the second theme, regarding the subject, 3 participants drew attention to the topic of awareness. Participant M5 and F3 stressed awareness, cases and compulsory courses through the following advisory statements: "SRE should be taught for at least three weeks. Especially the consultants should do it in the lecture on a specialized field. They should relay the related subjects to the students. They should guide them. Most importantly, they should create awareness." (M5) "The severity of the problem needs to be comprehended through materializing the issues of plagiarism and pilferage. Especially plagiarism should be associated with daily events. Cases should be touched on. SRE should be taught not only in the postgraduate education but also in the undergraduate education, and it should be made sure that students take responsibilities and develop awareness."

One participant suggested "beliefs and values, empathy, awareness on the part of instructor". Mentioning beliefs and values as a suggestion, participant M3 supported his/her opinion, saying "SRE education should be taught at the beginning. Integrity underlies ethics. These are called values. This is nothing to be taught in one course. We regard everything serving our goal as reasonable." Participant F2 added the SRE thesis to the suggestions through the statements "Students learn about SRE in prac- tice during the thesis stage; instead, a Scientific Research thesis may be prepared." Calling attention to the awareness on the part of instructors, participant M2 expressed his personal view, saying "I would like all advisors to emphasize scientific research ethics in all courses; moreover, researchers should be encouraged to develop awareness and take responsibility through showing the cited parts on the source." Participant M1 emphasized empathy and cases through the statements "Empathy should be developed. Just as they would be uncomfortable if their papers were to be given to the instructor without their consent, they should approach others' situation accordingly. In addition, no one intervenes in terms of confidentiality. An awareness of permission for utilization should be created; especially true life events around us." Finally, under the extrinsic ethics theme, 3 participants emphasized cases and 1 participant stated example regarding the issue.

\section{CONCLUSION AND DISCUSSION}

According to most of the participants, the knowledge of graduate students on SRE is inadequate. The participants reported that the students realized this deficiency of theirs during the thesis stage through experiences. The statements of participant M5 "My previous thesis student failed just because of that; we wrote the thesis all over again" reveal students' deficiency for this matter and need for support that the students learn the information on SRE during the process through experiences. This findings could be compared with the study of Yuan et al. (2015) who stated that poor writing skills and academic misconduct of Chinese post-graduate students and Türkyılmaz and Kaygisız (2012) results in not knowing how to 
refer to sources $(18 \%)$; revealing weak studying skills (20\%); lack of information-finding skills $(5 \%)$; insufficient understanding of research $(8 \%)$; and all of the before-mentioned factors (49\%).

While majority of the advisors stated that graduate students did not receive adequate education on SRE, some of them reported that the education which was given in Scientific Research Methods (SRM) course during the postgraduate process was not adequate enough. Additionally, these findings fit with the views of graduate students (Hamutoğlu, Yild1z and Akgün, 2015) through the statements: "They take the SRM course in the doctorate/master programs but I think it remains on the theoretical level. I believe these studies should be performed one-to-one. Once, I showed a thesis student how it works", participant F2 stated that students acquired information they had about SRE in SRM course, but reminded that that kind of information remained on a theoretical level. The opinion of participant M5 "no one asks about SRE. 6 students participate in the seminar course. People are not interested in this matter" shows that the reason why the knowledge about this subject is on theoretical level is the lack of interest in SRE.

Majority of the participants reported that graduate students meet their need for SRE education with the books suggested by the advisor rather during the thesis stage, and that there are no courses concerning this matter directly taught. They also stated that they meet their need for SRE education with the source of HEC, SRM courses and lectures on SF as well. The findings show that students were not aware of their need for SRE until the thesis stage and they did not realise their deficiency in the subject. This can be associated with the fact that information on SRE remains on the theoretical level in SRM course, the level of awareness in the subject is not inadequate, and students are not interested in the subject.

Most of the participants stressed the importance of creating awareness and the theoretical information in the content of a book to be prepared in order to make up the deficiency of students in SRE. According to the advisors, students do not know what they do is against SRE, and this is caused by the fact that they are not aware of SRE and lack of knowledge. Participant M5 called attention to the necessity of preparing learning material and its scope by stating "The importance of the matter should be told. What is it? Why is it important? What is SRE? Why are there rules? Examples should be given concerning the plagiarism. One should say 'This is plagiarism. The reasons are this, that.' There is a problem in the dimension of faith and awareness; ethics is a matter of 'I can take it or leave it.' Types of plagiarism should be explained and exemplified. The problems in students' minds should be solved. The awareness that each letter in the written work belongs to that person should be instilled." And participant F1 supported the importance of awareness in the content to be prepared, saying "Scientific research ethics should be explained with examples rather than definitions. Ammar, Mandil and El-Feky (2016) implies the importance of honesty and responsibilities. Özder, Işıktaş and Erdoğan (2014) also emphasise that attitudes should be objective and honest towards the academic unethical behaviours of advisors, and that the supervision should be ensured, giving importance to the ethical issues. Awareness should be created for plagiarism and information on sanctions should be provided.

Two concepts on which the participants mostly dwelled concerning SRE are awareness and exemplary cases. It is regarded as important by the advisors that an awareness of SRE in the 
book to be prepared should be created through cases. In addition, a compulsory course on SRE is among the opinions and suggestions. There is a similar approach which shows the importance of academic non-optional courses and examples, given by the advisor to increase the academic ethics knowledge and awareness of students (Zhang and Zhu, 2016). According to the advisors, it is critical that the content is relayed systematically in a direction from theory to practice.

It is clearly seen that graduate students' SRE knowledge is very low according to views of their advisors. The views are mostly related with the "Extrinsic Ethics" theme. This theme is followed by procedural and intrinsic ethics theme. Extrinsic ethics usually involves the issue of relation between the society and science (Steneck, 2004). It helps to use the science while making the policies. The results show SRE curricula and the students' educational needs should mostly derive from social experiences.

This result comes from background of the students. The advisors views show that there are no adequate SRE courses in the curricula. They state that during the existıng SRM course on the undergraduate/ graduate level they learn academic ethics insufficiently. The students do learn how to write and pay attention to the SRE when they begin to write their thesis. In this way, the participants also state, the students do not read the thesis writing manual. Regarding this issue, the students meet their needs especially by meeting with their advisors and having experience. For advisors, Zhang and Zhu (2016) suggest setting a good example and serious advice on the academic ethics. This result could also be the reason of not having a direct course. Hollander (2009) points the importance of learning ethical theories from a course material and instruction. The advisors also drawn attention to awareness of SRE. To prevent future plagiarism, researchers and academicians should pay attention to it from the very beginning.

To sum up, it was reported by the participants that students' levels of awareness of SRE were low. Accordingly, it was emphasised that the importance of SRE should be instilled not only to postgraduate students but also to students on all levels. In all courses, every advisor should address the seriousness of the subject. The advisors also think that cases, examples and true life events will be effective in increasing students' levels of awareness of SRE. Developing empathy was mentioned as an important technique for creating awareness for the importance of SRE. Consequently it is thought that considering the findings of this study may help to improve students' levels of awareness on SRE. Furthermore, the importance of SRE course and awareness of the students about academic ethics should be taken into account from both student and academician perspectives. The academicians should be more focused on the ethics rules and policies not only from the side of education; they should also be more aware of the students' opinions about SRE; they also show its implementation in other fields such as health, business, IT, and communication. Research teams could be created within universities and they could focus on providing research and writing support to the students who are at thesis stage. Regarding systematic approach, the awareness regarding plagiarism should be increased from the undergraduate level to post graduate studies. It is also important to be aware of the values and respects others posses by regarding the ethics rules. 


\section{References}

Ammar,M. B. S., Mandil, A. and El-Feky, S. (2016). Ethics in health practice and research: an EMR perspective. Eastern Mediterranean Health Journal, 22(1), 61-62.

Briggle, A., Holbrook, J. B., Oppong, J., Hoffmann, J., Larsen, K. E. and Pluscht, P. (2016). Research Ethics Education in the STEM Disciplines: The Promises and Challenges of a Gaming Approach. Science and Engineering Ethics, 22(1), 237-250.

Corley, E. A., Kim, Y. and Scheufele, Y. A. (2016). Scientists' Ethical Obligations and Social Responsibility for Nanotechnology Research. Science and Engineering Ethics, 22(1), 111-132.

Engel, J. C. (2016). Ethical Standards of Scientific Research for Beginning Accounting Scholars.Business and Economic Research, 6 (1), ISSN 2162-4860.

Engle, T. J. and Smith, J. L. (1990). The ethical standards of accounting academics. Issues in Accounting Education, 5(1), 7-29.

Gastel and Day (2016). How to write and publish a scientific paper (eighth edition). Greenwood: California Santa Barbara.

Hamutoğlu, N. B. Yıldız, E. P. and Akgün, Ö. E. (2015). Lisansüstü Öğrencilerinin Bilimsel Araştırma Etiği İle İlgili Görüşleri Sakarya Üniversitesi Örneği. VII. Ulusal Lisansüstü Ĕ̆itim Sempozyumu Bildiriler Kitabı (ULES-7), 54-62.

Hollander, R. (Ed.). (2009). Ethics education and scientific and engineering research: What's been learned? What should be done? Summary of a workshop. Washington, DC: Center for Engineering, Ethics, and Society. National Academy of Engineering. The National Academies Press.

Joly, Y., So, D., Osien, G., Crimi, L., Bobrow, M., Chalmers, D., Wallace, S. E., Zeps, N. and Knoppers, B. (2016). A decision tool to guide the ethics review of a challenging breed of emerging genomic projects. European Journal of Human Genetics. doi:10.1038/ejhg.2015.279.

Köklü, N. (2003). Akademisyenlerin Bilimsel Araştırma Etiği Konusundaki Görüşleri. Eğitim Bilimleri ve Uygulama, 2 (4), 137-151.

Maya, İ. (2013). Akademisyenlerin meslek ahlakına aykırı olan davranışlara ilişkin algıları. (ÇOMÜ eğitim fakültesi örneği).Turkish Studies, 8(6), 491-509.

Öncü, Ö. (2010). Fikir ve Sanat Eserleri Hukukunda İktibas ve Sinırları. Yetkin Yayınevi: Ankara

Özder, H., Işıktaş, S. and Erdoğan F. (2014). Öğretim Elemanlarının Akademik Kurallardan Haberdar Olma ve Onaylama Dereceleri. Intertational Journal Of New Trends In Arts, Sports \& Science Education, 3(1), 22-37.

Pınar, İ. (2002). Akademisyenlerin etik değerleri üzerine bir araştırma. İstanbul Üniversitesi İşletme Fakültesi İşletme İktisadı Enstitüsü Dergisi, 13(43), 5-19.

Pruzan, P. (2016). Ethics and Responsibility in Scientific Research. Research Methodology, 273-306. 
Reyes, I. G., Kim, W. T. and Weaver, G. (2016). Teaching ethics in business schools: A conversation on disciplinary differences, academic provincialism, and the case for integrated pedagogy. Acad manag learn edu. doi:10.5465/amle.2014.0402.

Schienke, E., Baum, S., Tuana, N., Davis, K., and Keller, K. (2010). Intrinsic ethics regarding integrated assessment models for climate management. Science and Engineering Ethics: DOI. doi:10.1007/s11948-010-9209-3.

Schienke, E., Tuana, N., Brown, D., Davis, K., Keller, K., Shortle, J., et al. (2009). The role of the NSF broader impacts criterion in enhancing research ethics pedagogy. Social Epistemology, 23, 317-336.

Sevim, O. (2014). Akademik Etik Değerler Ölçeğinin Geliştirilmesi: Güvenirlik ve Geçerlik Çalışması. International Periodical For The Languages, Literature and History of Turkish or Turkic 9(6), 943-957.

Steneck, N. H. (2004). Introduction to the responsible conduct of research. Washington, DC: Government Printing Office.

Uçak, N. and Birinci H. (2008). Bilimsel Etik ve İntihal. Türk Kütüphaneciliği 22(2), 187-204.

Tavşancıl, E. and Aslan, E. (2001). İçerik analizi ve uygulama örnekleri. İstanbul: Epsilon Yayıncılık.

Tuana, N. (2010). Leading with ethics, aiming for policy: New opportunities for philosophy of science. Synthese, 177(3), 471-492.

Türkiye Bilimler Akademisi Bilim Etiği Komitesi. (2002). Bilimsel araştırmada etik ve sorunlar. Ankara: Türkiye Bilimler Akademisi Yayınları.

Türkyılmaz, E. and Kaygısız, O. (2012). Bilimsel yayıncılıkta etik sorunlar ve akademisyenlerin intihale bakış1. Atatürk Üniversitesi Eğitim Fakültesi, Bilgi ve Belge Yönetimi Bölümü, Erzurum.

Yıldırım, A. and Şimşek, H. (2006). Nitel araştırma yöntemleri. Ankara: Seçkin Yayınevi.

Yuan, B.T., Wang, C.Y., Wu, Q. (2015). An empirical research on postgraduates' academic contributions. Res. High. Educ. Eng., 1, 154-160 (in Chinese).

Zhang, H. Y. (2015). Promoting Awareness of Publication Ethics: Against Plagiarism: Part of the series Qualitative and Quantitative Analysis of Scientific and Scholarly Communication, 99-104.

Zhang, J. C. and Zhu, Y. (2016) China's graduate students need better education in scientific writing and publishing. Journal of Zhejiang University-SCIENCE B (Biomedicine E Biotechnology, 17(5), 409-412. 